\title{
Review of the genus Hovorestenia Santos-Silva (Coleoptera: Disteniidae)
}

\author{
Juan Pablo Botero ${ }^{1}$ \\ 1 Universidade de São Paulo (USP), Museu de Zoologia (MZUSP). São Paulo, SP, Brasil. \\ ORCID: http://orcid.org/0000-0002-5547-7987.E-mail:jp_bot@yahoo.com
}

\begin{abstract}
Hovorestenia Santos-Silva, 2007 is a disteniid genus differentiated from other Neotropical Disteniini by the metatarsomeres II and V subequal in length, in contrast with the metatarsomere V distinctly longer than II in the other genera. So far, the genus is known only from male specimens. The discovery of new Hovorestenia species, represented by both sexes, shows that such current diagnostic character is sexually dimorphic, with metatarsomere V distinctly longer than II in female. The genus Hovorestenia is therefore reviewed and redescribed and two new species are described: H. cleideae, from Colombia and Ecuador, and H. espilota, from Colombia. It allowed to describe the hitherto unknown females and to appoint out sexually dimorphic characters for the first time in the genus. The genus is now composed of four species distributed from the central region of Colombia to Ecuador. Photographs of Hovorestenia species are included and a key to differentiate them is provided.
\end{abstract}

Key-Words. Colombia; Ecuador; Key; New species; Taxonomy; Sexual dimorphism.

\section{INTRODUCTION}

Hovorestenia was described by Santos-Silva (in Santos-Silva \& Hovore, 2007) for a single species, Distenia humeralis Waterhouse, 1880, described from Ecuador, and characterized by the following combination of characters: eyes finely faceted; pronotum lacking central gibbosity; metatarsomere V, about as long as II. Later, Santos-Silva \& Hovore (2008) described a second species, H. thalassina, also from Ecuador.

Currently, the genus is composed of these two species and known only from the equatorial Amazonian region (Monné, 2019; Tavakilian \& Chevillotte, 2019). Furthermore, the two species are known only from males, the females of the genus have been so far unknown.

Herein, two new species are described, including female specimens which enables description of sexual dimorphism of the genus. Additionally, the geographic range of the genus is expanded to the north, now reaching the central region of Colombia.

\section{MATERIAL AND METHODS}

The material is originated from the following institutions, which are subsequently referred to by their acronyms:

BMNH: The Natural History Museum, London, UK; IAVH: Instituto de Investigaciones de Recursos
Biológicos "Alexander von Humboldt", Villa de Leyva, Colombia; MZSP: Museu de Zoologia, Universidade de São Paulo, São Paulo, Brazil; QCAZ: Museo de Zoología de la Pontificia Universidad Católica del Ecuador, Quito, Ecuador; USNM: National Museum of Natural History, Smithsonian Institution, Washington, DC, USA.

Photographs were taken in the MZSP with a Canon EOS Rebel T3i DSLR camera, Canon MP-E $65 \mathrm{~mm}$ f/2.8 1-5× macro lens, controlled by Zerene Stacker AutoMontage software. The references and geographical distribution were verified in the catalogs of Monné (2019) and Tavakilian \& Chevillotte (2019) catalogs. The maps were made using the ArcGIS ESRI software version 9.3.

\section{TAXONOMY}

\section{Hovorestenia Santos-Silva, 2007}

Hovorestenia Santos-Silva, in Santos-Silva \& Hovore, 2007: 14; 2008: 2; Santos-Silva \& Martins, 2010: 105; Monné, 2012: 135; 2019: 219.

Type-species: Distenia humeralis Waterhouse, 1880 (original designation).

Redescription: Head prognathous, subparallel-sided behind eyes, then narrowed toward occiput. Eyes finely faceted, upper eye lobes 
well-separated, distance between them at least 2.5 times width of upper lobe. Antennae longer than body in both sexes; antennomeres gradually thinner toward apex. Fourth maxillary palpomere sexually dimorphic, securiform in male, fusiform in female. Prothorax slightly wider than long (including lateral tubercles), with median lateral tubercle; pronotum punctate, with four discal gibbosities. Elytra at least four times as long as prothorax; with two distinct areas of punctation: coarse and deeply punctate anteriorly and finely punctate posteriorly, in male, the border between those areas is sharp and marked by a pubescent band, in female the change in punctation is more gradual and the border is not well-defined; elytral apex with long spine at outer angle. Femora subfusiform; apex unarmed. Metatarsomere I as long as II + III together; metatarsomere $\mathrm{V}$ subequal in length to that of II in male, and at least 1.5 times as long as II in female.

Remarks: Hovorestenia differs from the other American genera of Disteniini by the following combination of characters: eyes finely faceted; pronotum lacking central gibbosity; elytra with coarse and deep punctation anteriorly and fine punctation posteriorly; metatarsomere $\mathrm{V}$,
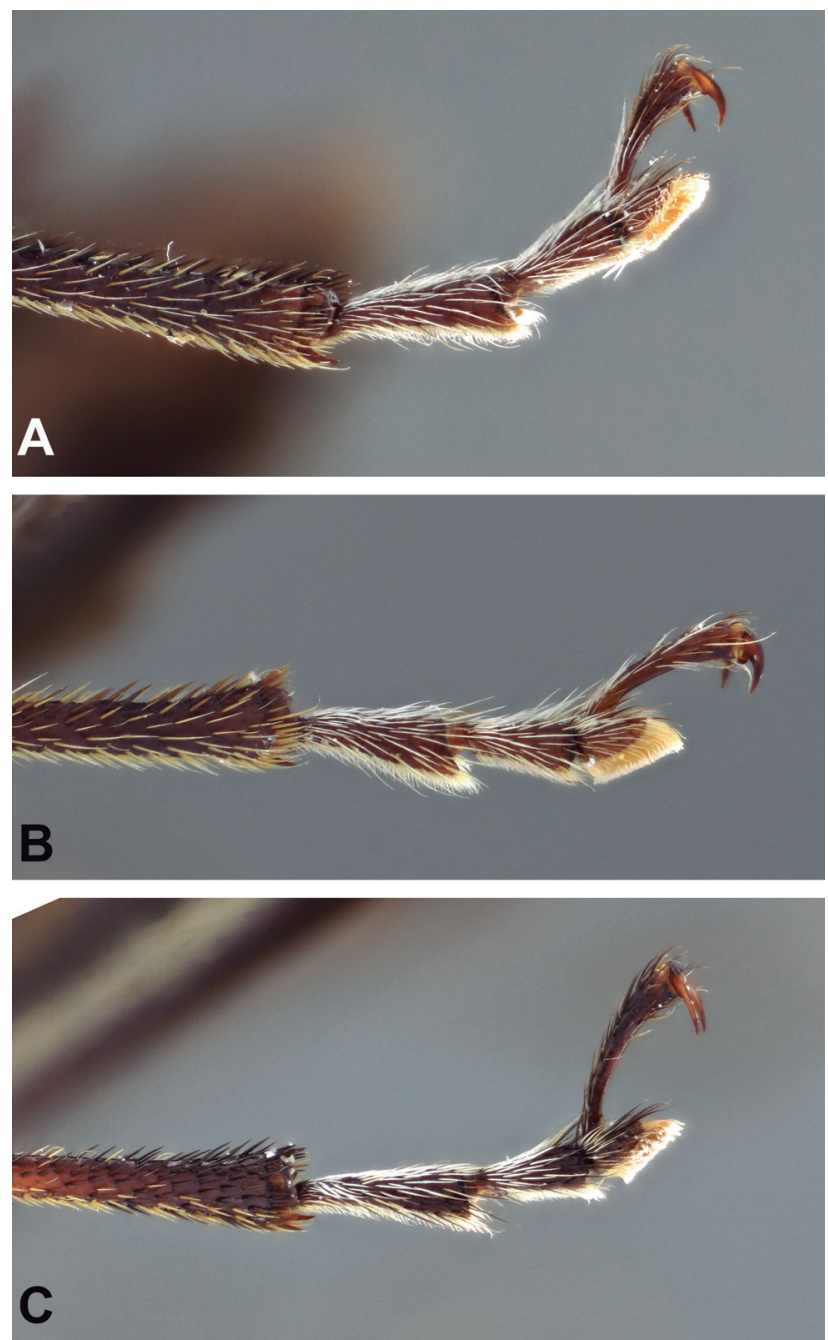

Figure 1. Detail of metatarsi: (A) Hovorestenia cleideae sp. nov., holotype male; (B) H. cleideae sp. nov., paratype female; (C) H. espilota sp. nov., holotype female. about as long as II (Fig. 1A) in male, and longer than II (Figs. 1B-C) in female.

Hovorestenia resembles Nethinius Fairmaire, 1889, from Madagascar and the Comores, by the pronotum without central gibbosity combined with the slender body, but differs by the antennae, at most, $1 / 3$ longer than the body (about twice the body length in Nethinius) and the apex of the elytra with external spine (without external spine in Nethinius).

In the most recent key for the genera of Disteniini Santos-Silva \& Martins (2010) differentiated Hovorestenia in the first couplet by the metatarsomeres II and V subequal in length (metatarsomere $\mathrm{V}$ distinctly longer than II in other American genera). Santos-Silva \& Martins (op. cit.) proposed the key when the genera was known only by male specimens. Now, with the discovery of new Hovorestenia species, represented by both sexes, this step turned out to be useless for females, which have the metatarsomere V longer than II. Therefore, the first couplet of the key is modified as follows:

1. Elytra with two distinct areas of punctation: coarse and deeply punctate anteriorly and very finely punctate posteriorly; males with metatarsomeres II and V subequal in length ..

Hovorestenia Santos-Silva, 2007

- Elytra uniformly punctate or the punctation gradually finer toward the apex; males and females with metatarsomere $\mathrm{V}$ longer than $I I . . . . .2$

\section{Key to species of Hovorestenia}

1. Elytra with orange longitudinal band on humeral region (Figs. 2-3, 7)...2

- Elytra without orange longitudinal band (Figs. 6, 8) ......................... 3

2(1). Surface of body with fine, sparse setae; head with fine punctation; pronotum with fine and alveolate punctation, anterior pronotal tubercles glabrous; longitudinal band of elytra starting at humeri; body size smaller (average total length from type series $=10.9 \mathrm{~mm}$ ) (Figs. 1A-B, 2-5). Colombia (Caquetá, Cundinamarca, Huila, Nariño), Ecuador ............................................ Hovorestenia cleideae sp. nov.

- Surface of body with coarse and dense setae; head with coarse and dense punctation; pronotum with coarse and confluent punctation, pronotal tubercles punctate; longitudinal band of elytra starting beyond humeri; body size larger (average total length $=13.9 \mathrm{~mm}$ ) (Fig. 7). Ecuador............ Hovorestenia humeralis (Waterhouse, 1880)

3(1). Elytra with oblique grayish pubescent band on midlength, without spot of grayish pubescence; apices of coxae and trochanters, base and ventral face of femora, and tibiae reddish brown. (Figs. 1C, 6). Colombia (Cauca). Hovorestenia espilota sp. nov.

- Elytra with oblique pubescent band on posterior fourth and with a pair of grayish pubescent spots at midlength; reddish-brown areas of legs restricted to trochanters and bases of femora and tibiae. (Fig. 8). Ecuador ........... Hovorestenia thalassina Santos-Silva \& Hovore, 2007

\section{Hovorestenia cleideae sp. nov. \\ (Figs. 1A-B; 2-5)}

Type material: Holotype ơ (IAVH): Colombia, Caquetá: San José del Fragua (Vereda La Esmeralda, $01^{\circ} 20^{\prime} \mathrm{N}$, 7606’W, 1,350 m), 09-13.IX.2000, González E. col., 

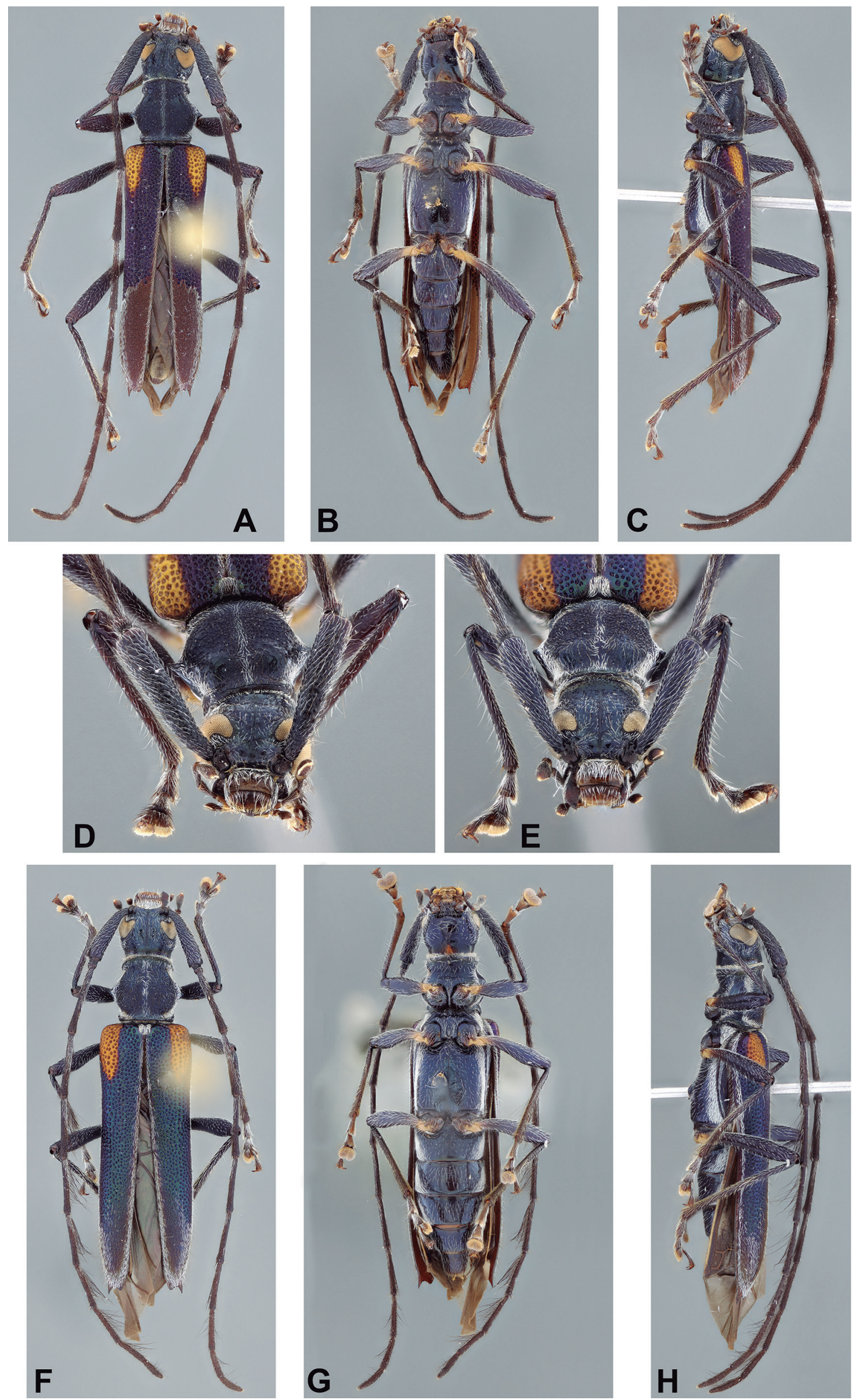

Figure 2. Hovorestenia cleideae sp. nov. (A-D) Holotype male: (A) dorsal habitus; (B) ventral habitus; (C) lateral habitus; (D) head, frontal. (E-H) Paratype female: (E) head, frontal; (F) dorsal habitus; (G) ventral habitus; (H) lateral habitus. 
Malaise, IAvH-E-203842. Paratypes: Same data as holotype: 10", IAvH-E-203765 (IAVH); 6\%, IAvH-E-203761, IAvH-E-203793， IAvH-E-203795， IAvH-E-203802, IAvH-E-203841 (5 IAVH, 1 MZSP); Caquetá: San José de Fragua (R. Yuruyaco, $01^{\circ} 20^{\prime} 55^{\prime \prime} \mathrm{N}, 76^{\circ} 06^{\prime} 11^{\prime \prime} \mathrm{W}, 1,250 \mathrm{~m}$ ), 19,09-13.IX.2000, González E. col., Malaise, IAvH-E-214335 (IAvH); Cundinamarca (PNN Chingaza Bosque Palacio, $\left.04^{\circ} 31^{\prime} \mathrm{N}, 73^{\circ} 45^{\prime} \mathrm{W}, 2,930 \mathrm{~m}\right), 39,18-20 . \mathrm{VIII} .2000$, Cifuentes L. col., Winkler, IAvH-E-203763, IAvH-E-203807 (2 IAVH, 1 MZSP); Huila (PNN Cueva de los Guácharos, Cabaña Cedros, $\left.01^{\circ} 37^{\prime} \mathrm{N}, 76^{\circ} 06^{\prime} \mathrm{W}, 2,100 \mathrm{~m}\right), 19,27 . \mathrm{XI}-02 . \mathrm{XII.2001}$, D. Campos col., Malaise, IAvH-E-203784 (IAVH); 1, 10-21. XII.2001, Cortés C. col., Malaise, IAvH-E-203804 (IAVH); (PNN Cueva de los Guácharos, Cascajosa, $01^{\circ} 36^{\prime} \mathrm{N}$, 7606'W, 1,750 m), 19, 04-18.XI.2002, Urbano J. col. Malaise, IAvH-E-2144337 (IAvH); Nariño (Territorio Kofán, $\left.00^{\circ} 28^{\prime} 49^{\prime \prime} \mathrm{N}, 77^{\circ} 17^{\prime} 35^{\prime \prime} \mathrm{W}, 1,430 \mathrm{~m}\right), 19,24 . \mathrm{IX} .1998, \mathrm{E}$. González col., Malaise, IAvH-E-01749 (IAVH).

Additional material examined: Ecuador, Napo: Cosanga $\left(00^{\circ} 37^{\prime} 01.7^{\prime \prime} \mathrm{S}, 77^{\circ} 52^{\prime} 59.8^{\prime \prime} \mathrm{W}, 2,117 \mathrm{~m}\right), 1$, 14.X.2013, Jim McClarin col. This specimen should have been deposited in the QCAZ but, unfortunately, it was lost (Jim McClarin pers. comm.). It is included in order to add Ecuador to the distribution of the new species. Photographs of this specimen are available at: https:// www.flickr.com/photos/36494393@N00/14019327088/ in/album-72157649421153367.

Description (Male): Integument dark brown with metallic-blue reflections, head and pronotum slightly greenish. Mouthparts, tibiae and ventral surface of body lighter; tro- chanters and bases of femora orange. Each elytron with orange fascia, starting on humerus and reaching about onefourth of elytral length, gradually narrowing posteriorly.

Head: Vertex with fine, sparse, shallow punctures, with sparse, erect short setae, denser and longer between antennal tubercles and margin of upper eye lobes; frons finely, sparsely punctate, laterally with whitish erect setae; frontoclypeal suture and basal $3 / 4$ of clypeus with long whitish setae; labrum with long, erect whitish setae and interspersed shorter setae; genae short, apex truncate, with dense whitish setae. Distance between upper eye lobes about 3 times width of one upper lobe. Gulamentum smooth, transversely impressed anteriorly, with long, sparse whitish setae. Antennae reaching elytral apex at antennomere VII; scape with short whitish setae, with darker longer setae interspersed; antennomeres finely punctate; III with basal ring of whitish pubescence; IV-XI with whitish pubescence on basal fourth (less evident toward apical antennomeres) and dark pubescence on remaining surface; scape slightly curved basally, subcylindrical; antennal formula (ratio) based on length of antennomere III (only holotype measured): scape $=0.99$; pedicel $=0.06 ; \mathrm{IV}=0.88 ; \mathrm{V}=0.88 ; \mathrm{VI}=0.79$; $\mathrm{VII}=0.72 ; \mathrm{VIII}=0.65 ; \mathrm{IX}=0.61 ; \mathrm{X}=0.54 ; \mathrm{XI}=0.64$.

Thorax: Prothorax transverse, 1.2 times as wide as long (including lateral tubercles); with anterior and posterior constriction; lateral tubercles acute. Surface of pronotum densely and coarsely alveolate, with short, moderately dense dark setae and interspersed sparser longer setae; margins of pronotum and complete median longitudinal
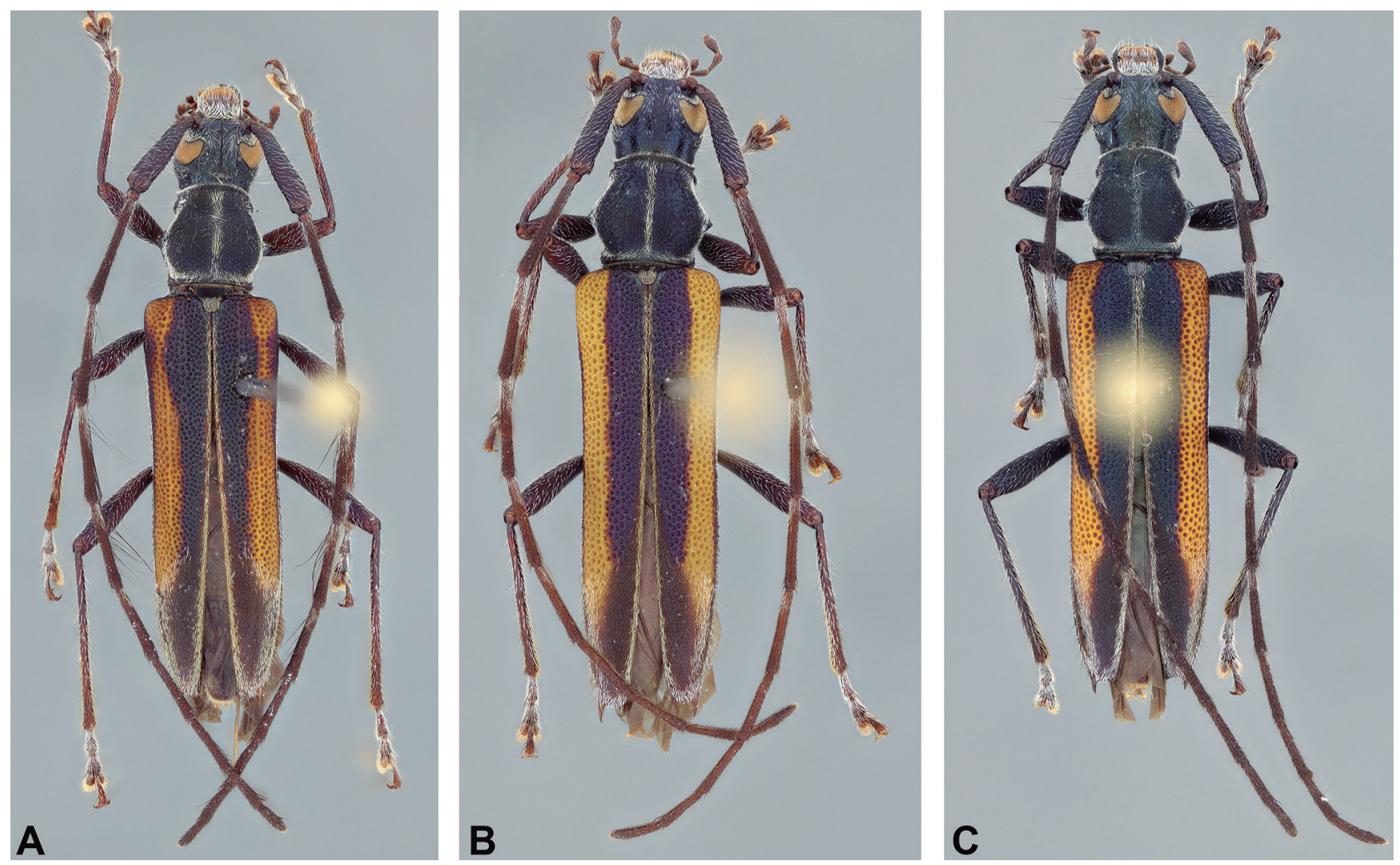

Figure 3. Hovorestenia cleideae sp. nov., paratypes female, dorsal habitus: (A-B) from Colombia, Caquetá; (C) from Colombia, Cundinamarca. 

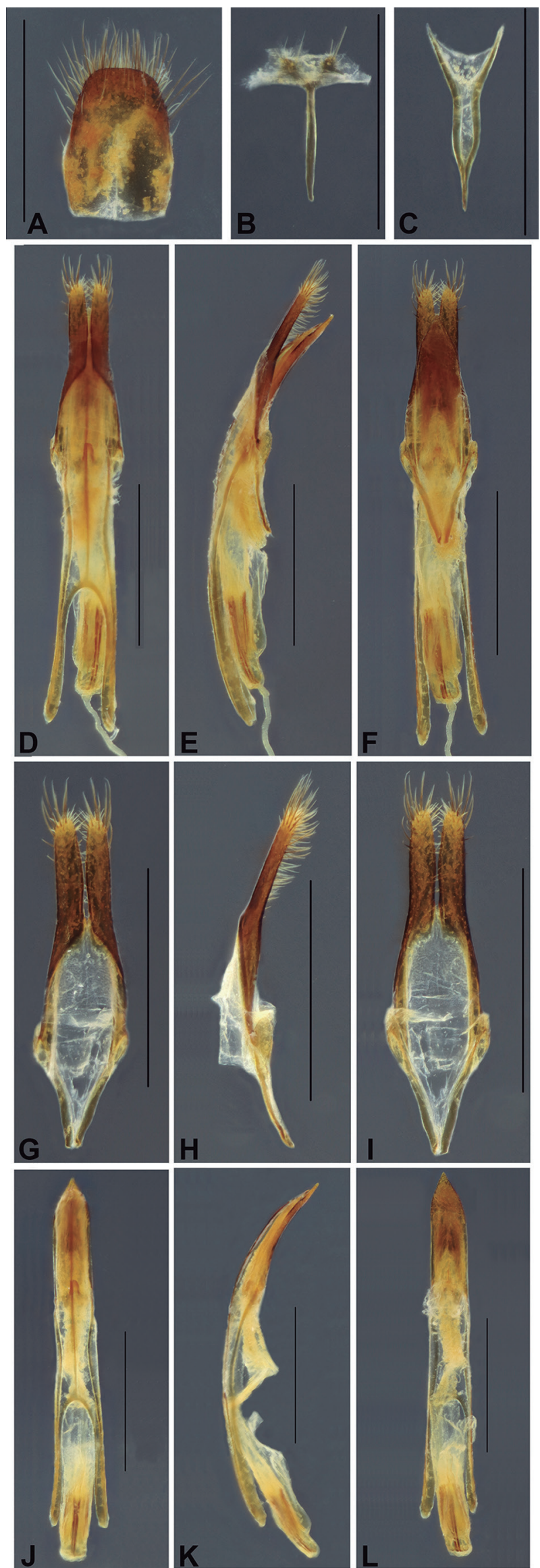

Figure 4. Hovorestenia cleideae sp. nov., male: (A) tergite VIII; (B) sternite VIII; (C) ventral arc; (D-F) tegmen + median lobe: (D) dorsal view; (E) lateral view; (F) ventral view. (G-I) tegmen: (G) dorsal; (H) lateral; (I) ventral. (J-L) median lobe: (J) dorsal; (K) lateral; (L) ventral. Scale bar $=1 \mathrm{~mm}$. band with dense, coarse whitish setae; pronotum with two pairs of weakly elevated gibbosities, anterior pair glabrous. Prosternum with deep transverse sulcus and fine transverse wrinkles; with long, sparse whitish setae on anterior and posterior margins, and short, dense whitish setae laterally; prosternal process subparallel-sided, apex rounded; width at narrowest point equal to $1 / 8$ of procoxal cavity width. Mesoventrite anteriorly impressed, smooth, posteriorly and on mesoventral process with long, sparse whitish setae; mesoventral process emarginate at posterior margin, with apex about $3 / 4$ of mesocoxal cavity width. Mesanepisternum, mesepimeron and metanepisternum with short, dense whitish setae, obscuring surface. Metaventrite sparsely, finely punctate; on central area, each puncture with long, erect whitish seta; with short dense whitish setae laterally. Scutellum with short, dense whitish pubescence; apex rounded. Elytra subparallel-sided, almost four times as long as prothorax; with coarse deep punctation from humeri to posterior third, with very fine, dense punctation on posterior third; lateral and sutural margins covered with short and dense grayish pubescence; with oblique band of dense grayish pubescence separating regions of coarse and fine punctation, starting at epipleura and reaching suture; apex of elytra truncate. Femora with short, moderately sparse whitish setae, longer ventrally; tibiae with short whitish setae, with longer setae interspersed.

Abdomen: Ventrites finely, sparsely punctate; with long, sparse whitish setae on central region and short, dense setae laterally, obscuring integument; ventrites gradually decreasing in width toward last ventrite; apex of ventrite $\mathrm{V}$ truncate.

Terminalia: Tergite VIII (Fig. 4A) with distal margin truncate and lined with both, long and short yellow setae.

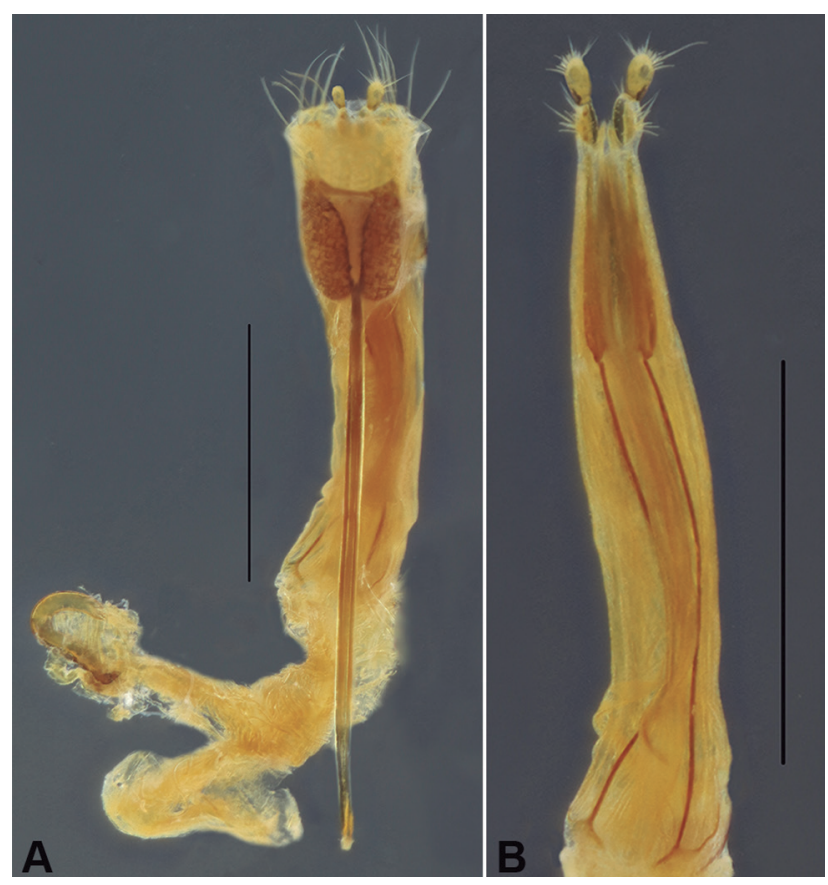

Figure 5. Hovorestenia cleideae sp. nov., female: (A) terminalia, ventral; (B) genitalia, ventral. Scale bar $=1 \mathrm{~mm}$. 

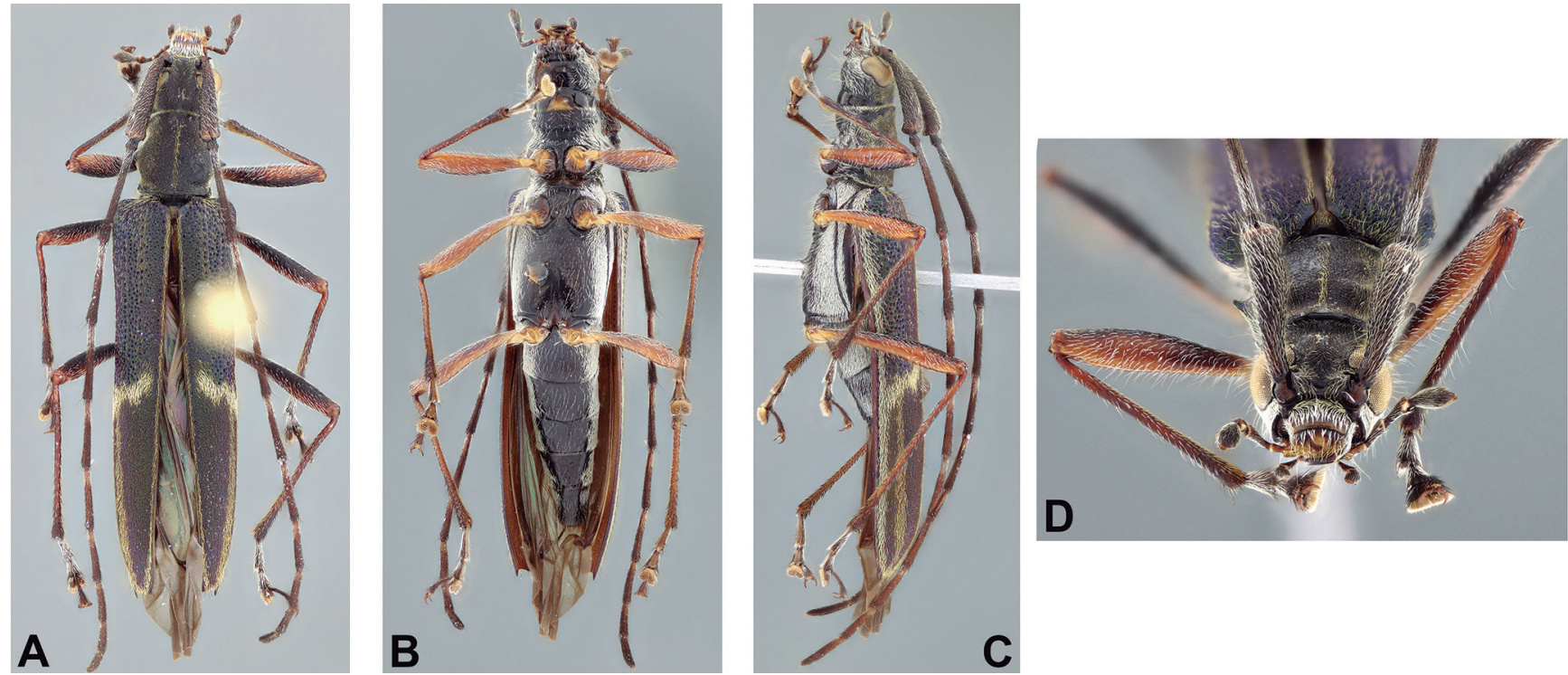

Figure 6. Hovorestenia espilota sp. nov., holotype female. (A-C) habitus: (A) dorsal; (B) ventral; (C) lateral. (D) head, frontal.

Sternite VIII (Fig. 4B) transverse, distal margin strongly sinuous, with long yellow setae laterally, decreasing in length to middle; apophysis long, about three times as long as sternite. Ventral arc (Fig. 4C) fork-shaped, with apophysis short, about $1 / 3$ as long as arms; arms sinuous. Dorsal arc was not found in the dissected specimen, it is probably absent. Tegmen (Figs. 4G-I) about 0.6 times length of median lobe; distal region completely divided into parameres; parameres cylindrical-elongated, apex rounded and bearing both short and long setae; ring piece elongated, proximal part connected only by narrow membrane, without projection. Median lobe (Figs. 4J-L) slightly curved in lateral view; dorsal lobe with apex rounded and not reaching the acuminate apex of ventral lobe; basal apophysis about $2 / 3$ length of apical region.

Female: Antennae reaching elytral apex at antennomere VIII; separation between coarsely and finely punctate areas of elytra not sharp, and more gradual than in male, not delineated by grayish pubescence; with more grayish pubescence at apex of elytra. Length of metatarsomere $\mathrm{V}$ at least 1.5 times the length of metatarsomere II.

Terminalia: Sternite VIII (Fig. 5A) elongate; sternal apophysis about four times as long as apical region of sternite; segment IX (Fig. 5B) membranous and shaped like an elongate sac. Ovipositor (Fig. 5B) long; distal region with subcylindrical short coxites; apical region with a small cylindrical stylus. Spermatheca tubular, "C" shaped.

Variation: In some specimens the orange fascia of elytra can be longer than in the holotype, reaching the apical fourth (Fig. 3). This variation was observed only in females, but it is probably an intraspecific variation, not associated to sexual dimorphism.

Dimensions (mm): Holotype male. Total length, 10.5; prothoracic length, 1.8; anterior prothoracic width, 1.3; posterior prothoracic width, 1.4; widest prothoracic width (between apices of lateral tubercles), 2.1; humeral width, 2.3; elytral length, 7.1. Paratypes male $(n=1)$ / female $(n=12)$. Total length, $10.9 / 10.96 \pm 0.64$; prothoracic length, $1.8 / 1.81 \pm 0.13$; basal prothoracic width, 1.4/1.48 \pm 0.12 ; distal prothoracic width, 1.5/1.62 \pm 0.13 ; widest prothoracic width (between apices of lateral tubercles), 2.1/2.21 \pm 0.17 ; humeral width, 2.4/2.51 \pm 0.18 ; elytral length, 7.6/7.72 \pm 0.51 .

Etymology: This species is named in honor of Dr. Cleide Costa, for her invaluable contributions to the knowledge of the immatures of Coleoptera.

Remarks: Hovorestenia cleideae sp. nov., is similar to H. humeralis (Fig. 7) in having the elytra with an orange longitudinal band on the humeral region, but differs as follows ( $H$. humeralis in parenthesis): surface of body with fine, sparse setae, especially ventrally and on legs (with coarse and denser setae); head finely punctate (with coarse and dense punctation); pronotum with fine and alveolate punctation and anterior tubercles glabrous (with coarse and confluent punctation, and pronotal tubercles punctate); longitudinal band of elytra starting on humeri (starting beyond humeri); and body size smaller, average total length $=10.9 \mathrm{~mm}$ (the specimen measured has $13.9 \mathrm{~mm}$ ).

\section{Hovorestenia espilota sp. nov. (Figs. 1C, 6)}

Type material: Holotype $q$ (IAVH): Colombia, Cauca (PNN Munchique Sector La Romelia, $02^{\circ} 38^{\prime} \mathrm{N}, 73^{\circ} 52^{\prime} \mathrm{W}, 2,650 \mathrm{~m}$ ), 24.V-09.VI.2004, Fino E. col. Malaise, IAvH-E-203768.

Description (Female): Integument dark brown with metallic-blue reflections. Mouthparts, apex of scape and antennomeres, gradually to the apex of antenna, lighter; coxae, trochanters and femora laterally and ventrally, and basal $3 / 4$ of metatibiae reddish-brown. 
Head: Vertex with dense, coarse, shallow punctures, and dense, erect, short setae, denser and longer around margin of upper eye lobes and base of antennal tubercles; frons and antennal tubercles smooth except for a few punctures, with short, dense setae laterally; basal 3/4 of clypeus with long yellowish setae; labrum with long, erect whitish setae; genae short, apex truncate, with dense whitish setae. Distance between upper eye lobes about
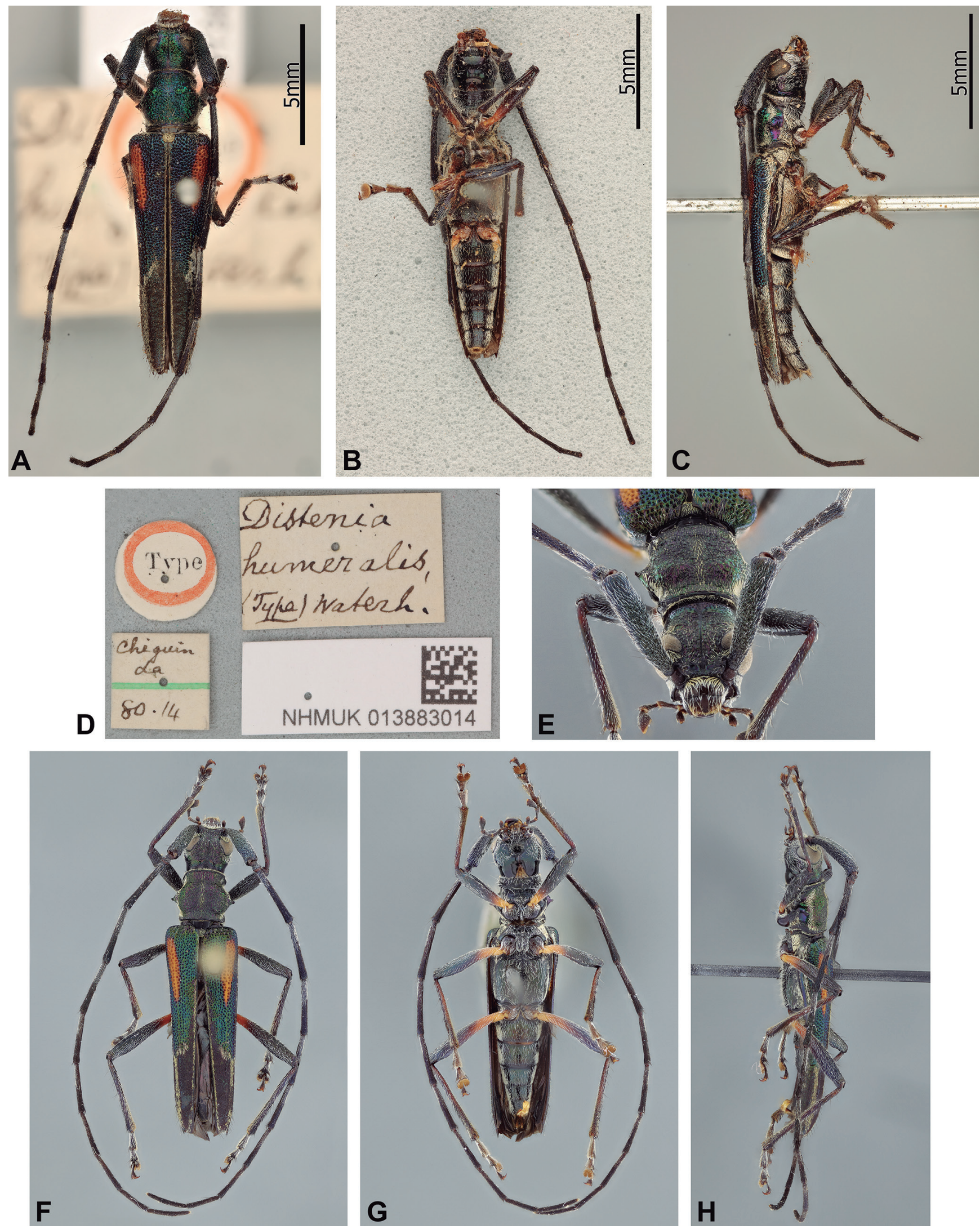

Figure 7. Hovorestenia humeralis (Waterhouse, 1880), male. (A-D) Holotype: (A) dorsal habitus; (B) ventral habitus; (C) lateral habitus; (D) labels. (E-H) Specimen 1: (E) head, frontal; (F) dorsal habitus; (G) ventral habitus; (H) lateral habitus. 


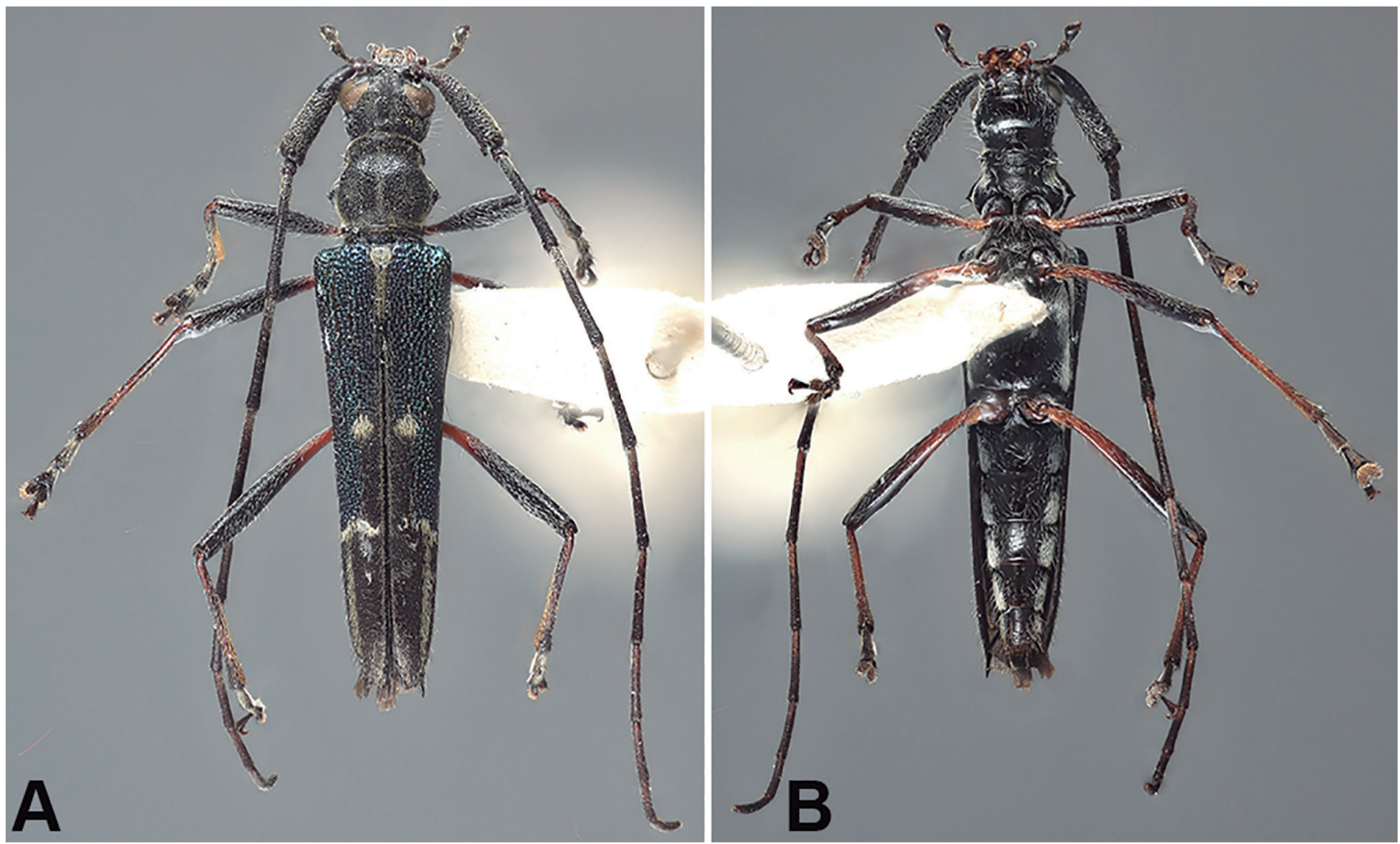

Figure 8. Hovorestenia thalassina Santos-Silva \& Hovore 2008, holotype male. Habitus: (A) dorsal; (B) ventral.

2.5 times width of one upper lobe. Gulamentum smooth, strongly impressed anteriorly, with long, sparse whitish setae. Antennae reaching elytral apex at antennomere IX; scape with short whitish setae and interspersed longer setae; antennomeres finely punctate, with short and dense setae, yellowish basally, darker on remaining surface; scape curved basally, progressively dilated toward apex; antennal formula (ratio) based on length of antennomere III: scape $=0.91$; pedicel $=0.11 ; \mathrm{IV}=0.82 ; \mathrm{V}=0.77$; $\mathrm{VI}=0.68 ; \mathrm{VII}=0.64 ; \mathrm{VIII}=0.57 ; \mathrm{IX}=0.50 ; \mathrm{X}=0.41 ; \mathrm{XI}=0.43$.

Thorax: Prothorax transverse, 1.22 times as wide as long (including lateral tubercles); with anterior and posterior constriction; lateral tubercles rounded. Surface of pronotum densely, coarsely, confluently punctate; with short, dense yellowish setae, denser laterally and medially, forming median longitudinal band from anterior to posterior margin; with two pairs of weakly elevated gibbosities. Prosternum with deep, transverse sulcus, smooth, with long, sparse whitish setae on anterior margin and short and dense whitish setae laterally; prosternal process gradually narrowed toward truncate apex; width at narrowest point equal to $1 / 6$ of procoxal cavity width. Mesoventrite with long, sparse whitish setae, and short, dense whitish setae laterally; mesoventral process emarginate at posterior margin, with apex equal to $3 / 4$ of mesocoxal cavity width. Mesanepisternum, mesepimeron and metanepisternum with short, dense whitish setae obscuring integument. Metaventrite finely punctate, at central area each puncture with long, erect whitish seta; with short dense whitish setae laterally. Scutellum with short, dense pubescence; apex rounded. Elytra gradu- ally narrowed toward apex, almost five times as long as prothorax; with coarse, deep punctation from humeri to midlength and with fine, dense punctation on posterior half; margins covered with short, dense grayish pubescence; with oblique band of dense grayish pubescence separating anterior and posterior half, starting at epipleura and almost reaching suture; apex of elytra obliquely truncate, with small dentiform projection at sutural angle. Femora with short, dense whitish setae, longer, sparser ventrally; tibiae with short whitish setae, denser, darker toward apex. Femora more linear toward metafemora; length of metatarsomere $\mathrm{V}$ twice length of metatarsomere II.

Abdomen: Ventrites finely, sparsely punctate; with both, short and long, sparse setae on central region, and short, dense setae laterally obscuring integument; ventrites gradually decreasing in width toward last ventrite; apex of ventrite $V$ truncate.

Dimensions (mm): Holotype female. Total length, 12.4; prothoracic length, 1.8; anterior prothoracic width, 1.4; posterior prothoracic width, 1.6; widest prothoracic width (between apices of lateral tubercles), 2.2; humeral width, 2.7; elytral length, 8.8.

Etymology: A compound of the Latin "ex" (without; denoting privation) and the Greek "spilotos" (spotted), referring to the absence of a spot of grayish pubescence on elytra.

Remarks: Hovorestenia espilota sp. nov., resembles H. thalassina (Fig. 8), but differs by the absence of a spot of 


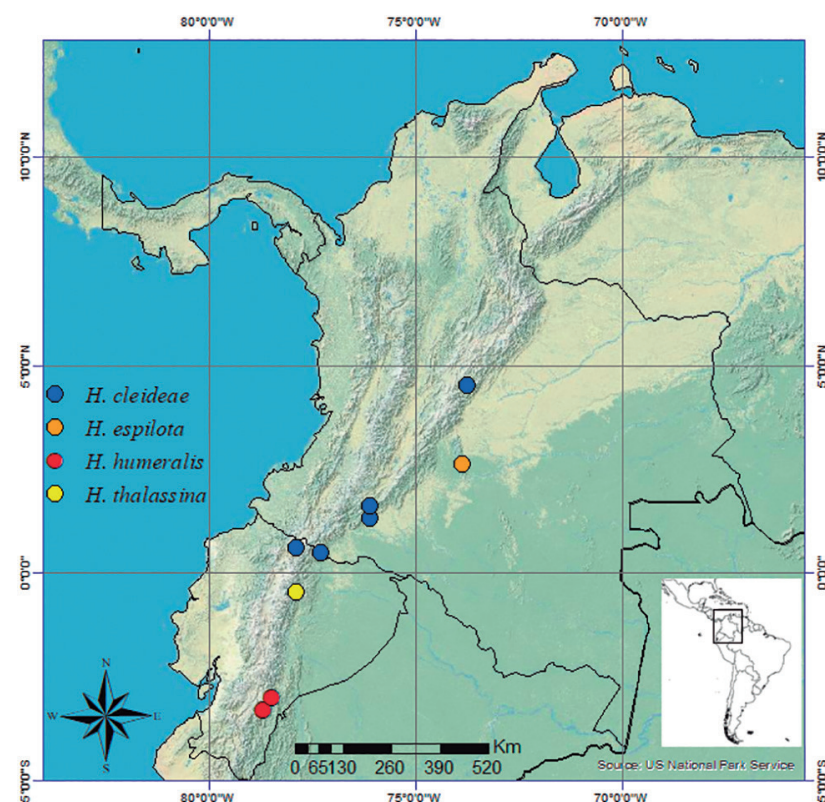

Figure 9. Geographical distribution of Hovorestenia species.

grayish pubescence on each elytron, area of finer punctation of the elytra covering almost entire posterior half, and femora dark dorsally and reddish-brown laterally and ventrally. In $H$. thalassina, each elytron has a spot of grayish pubescence, area of finer punctation of the elytra is placed on posterior fourth, and the femora are reddish-brown on basal third and the remaining surface is dark.

\section{Hovorestenia humeralis (Waterhouse, 1880)}

(Fig. 7)

Distenia humeralis Waterhouse, 1880: 295; Lameere, 1883: 19; Ross, 1911: 221; Aurivillius, 1912: 8; Boppe, 1921: 5; Blackwelder, 1946: 558; Villiers, 1959: 56; Monné \& Giesbert, 1994: 302; Monné \& Hovore, 2006: 302.

Hovorestenia humeralis; Santos-Silva \& Hovore, 2007: 15, figs. 31-34, 92; Santos-Silva \& Martins, 2010: 106, figs. 170, 189, 191, 192; Monné, 2019: 220.

Material examined: Ecuador, holotype ơ (photograph): Morona-Santiago: Chiguinda (BMNH); Zamora-Chinchipe (Plan Milagro, 1,948 m, 0300'596"S, 78³0'180"W), 10", 19.IX.2001, no collector indicated (MZSP).

Remarks: This species is known only from Ecuador (Fig. 9) and the females are unknown. The sex of the holotype was not indicated in original description, but through the study of its photograph, it was possible to observe that it is a male.

\section{Hovorestenia thalassina Santos-Silva \& Hovore, 2008} (Fig. 8)

Hovorestenia thalassina Santos-Silva \& Hovore, 2008: 2, figs. 1, 14; Santos-Silva \& Martins, 2010: 107, figs. 188, 193; Lingafelter et al., 2014: 333, figs. 170e, f (holotype); Monné, 2019: 220.

Material examined: Ecuador, holotype o': Napo: Quijos (Sierra Azul, Valle Hermoso) (USNM).

Remarks: This species is also known only from Ecuador (Fig. 9) and its females are unknown.

\section{ACKNOWLEDGMENTS}

The author is grateful to Antonio Santos-Silva (MZSP) for providing helpful comments on the manuscript; to Petr Švácha (Czech Academy of Sciences, Czech Republic), Larry G. Bezark, and Gabriel Biffi and Sônia Casari (MZSP) for their suggestions and comments; to Jhon Cesar Neita and Diana Espitia Reina (IAVH) for loan of the specimens of the new species; to Eugenio $\mathrm{H}$. Nearns (USNM) for the photographs of the holotypes of $H$. thalassina; to Beulah Garner (BMNH) for the photographs of the holotypes of $H$. humeralis; to Jim McClarin for the information on the specimen of $H$. cleideae sp. nov., from Ecuador; and to "Fundação de Amparo à Pesquisa do Estado de São Paulo" (FAPESP) for a postdoctoral fellowship (process number 2017/17898-0).

\section{REFERENCES}

Aurivillius, C. 1912. Coleopterorum Catalogus. Pars 39. Cerambycinae. Berlín, W. Junk. 574p.

Blackwelder, R.E. 1946. Checklist of the coleopterous insects of Mexico, Central America, the West Indies and South America. Part 4. Bulletin of the United States National Museum, Washington D.C., 185(4): 551-763.

Boppe, P.L. 1921. Genera Insectorum, Fam. Cerambycidae: subfam. DisteniinaeLepturinae. Bruxelles, P. Wytsman. p. 178: 1-119.

Lameere, A.A. 1883. Liste des cérambycides décrits postérieurement au catalogue de Munich. Annales de la Société Entomologique de Belgique, 26: 1-78.

Lingafelter, S.W.; Nearns, E.H.; Tavakilian, G.L.; Monné, M.A. \& Biondi, M. 2014. Longhorned Woodboring Beetles (Coleoptera, Cerambycidae and Disteniidae) Primary types of the Smithsonian Institution. Smithsonian Institution Scholarly Press, Washington, D.C. 390p.

Monné, M.A. 2012. Catalogue of the type-species of the genera of the Cerambycidae, Disteniidae, Oxypeltidae and Vesperidae (Coleoptera) of the Neotropical Region. Zootaxa, 3213: 1-183.

Monné, M.A. 2019. Catalogue of the Cerambycidae (Coleoptera) of the Neotropical Region. Part III. Subfamilies Lepturinae, Necydalinae, Parandrinae, Prioninae, Spondylidinae and families Oxypeltidae, Vesperidae and Disteniidae. Available at: $\mathrm{http}: / /$ cerambyxcat.com. Access in: 24/09/2019.

Monné, M.A. \& Giesbert, E.F. 1994. Checklist of the Cerambycidae and Disteniidae (Coleoptera) of the Western Hemisphere. Burbank, Wolfsgarden Books. 409p.

Monné, M.A. \& Hovore, F.T. 2006. A Checklist of the Cerambycidae, or longhorned wood-boring beetles, of the Western Hemisphere. Rancho Dominguez, Calif. Quip Publications. 394p.

Ross, E. 1911. Distenia Serville (1835). Internationalen Entomologischen Zeitschrift, 7(41): 220-222. 
Santos-Silva, A. \& Hovore, F.T. 2007. Divisão do gênero Distenia Lepeletier \& Audinet-Serville, notas sobre a venação alar em Disteniini, homonimías, sinonímia e redescrições (Coleoptera, Cerambycidae, Disteniinae). Papéis Avulsos de Zoologia, São Paulo, 47(1): 1-29.

Santos-Silva, A.\& Hovore, F.T. 2008. Novas espécies de Disteniinae americanas (Coleoptera, Cerambycidae). Les Cahiers Magellanes, 81: 1-16.

Santos-Silva, A. \& Martins, U.R. 2010. Subfamília Disteniinae, In: Martins, U.R. (Org.). Cerambycidae Sul-americanos (Coleoptera) Taxonomia. São Paulo, Sociedade Brasileira de Entomologia. pt. 11, p. 80-255.
Tavakilian, G. \& Chevillotte, H. 2019. Titan: base de données internationales sur les Cerambycidae ou Longicornes. Version 3.0. Available at: http://titan. gbif.fr. Access in: 24/09/2019.

Villiers, A. 1959. Essai sur les Distenia Américains (Col., Cerambycidae). Revue Française d'Entomologie, 22(2): 55-76.

Waterhouse, C.0. 1880. New South-American Coleoptera, chiefly from Ecuador. The Annals and Magazine of Natural History, (5)5: 285-302. 